\title{
Transcript levels of ten-eleven translocation type 1-3 in cervical cancer and non-cancerous cervical tissues
}

\author{
DOROTA EWA BRONOWICKA-KŁYS ${ }^{1}$, ANDRZEJ ROSZAK ${ }^{2,3}$, PIOTR PAWLIK ${ }^{4}$, \\ STEFAN SAJDAK $^{4}$, ANNA SOWIŃSKA ${ }^{5}$ and PAWEŁ PIOTR JAGODZIŃSKI ${ }^{1}$ \\ ${ }^{1}$ Department of Biochemistry and Molecular Biology, Poznań University of Medical Sciences, \\ Poznań 60-781; ${ }^{2}$ Department of Radiotherapy and Gynecological Oncology, Greater Poland Cancer Center; \\ ${ }^{3}$ Department of Electroradiology, Poznań University of Medical Sciences, Poznań 61-866; \\ ${ }^{4}$ Division of Gynecological Surgery, Poznań University of Medical Sciences, Poznań 60-535; \\ ${ }^{5}$ Department of Computer Science and Statistics, Poznań University of Medical Sciences, Poznań 60-529, Poland
}

Received April 26, 2016; Accepted January 26, 2017

DOI: $10.3892 / 01.2017 .5930$

\begin{abstract}
Decreased expression of ten-eleven translocation (TET1, TET2 and TET3) proteins has been reported in various types of cancer. However, the expression levels of TET proteins in cervical cancer (CC) remain to be elucidated. The present study determined the levels of TET1, TET2 and TET3 transcripts in cancerous $(n=80)$ and non-cancerous cervical tissues $(\mathrm{n}=41)$. The results revealed a significant reduction in TET1 transcripts $(\mathrm{P}=0.0000001)$ in cervical tissue samples from patients with primary CC compared with samples from control patients. Significantly decreased TET1 transcript levels, as compared to non-cancerous cervical tissues, were also observed in tissue samples with the following characteristics: Stage I ( $\mathrm{P}=0.016)$, II $(\mathrm{P}<0.0001)$, III $(\mathrm{P}=0.00007)$ and grade of differentiation $\mathrm{G} 1(\mathrm{P}=0.026), \mathrm{G} 2(\mathrm{P}=0.00006), \mathrm{G} 3$ $(\mathrm{P}=0.0007)$ and $\mathrm{Gx}(\mathrm{P}=0.0004)$ and squamous histological type $(\mathrm{P}<0.00001)$. TET1 transcript levels were significantly lower in patients aged $45-60$ years $(\mathrm{P}=0.0002)$ and patients age $>60$ years $(\mathrm{P}=0.003)$, as compared with non-cancerous cervical tissues. TET2 transcript levels were lower in cervical cancer tissues classified as stage II $(\mathrm{P}=0.043)$ and TET3 transcript levels were lower in stage III samples $(\mathrm{P}=0.010)$, tissue samples with a grade of differentiation of $\mathrm{G} 3(\mathrm{P}=0.025)$ and tissue with squamous type histology $(\mathrm{P}=0.047)$, all compared with non-cancerous cervical tissues. The present study demonstrated a significantly reduced level of TET1 transcripts in cancerous cervical tissues, as compared with non-cancerous tissues. Furthermore, decreased TET1-3 transcript levels were identified when patients with $\mathrm{CC}$ were
\end{abstract}

Correspondence to: Professor Paweł Piotr Jagodziński, Department of Biochemistry and Molecular Biology, Poznań University of Medical Sciences, 6 Święcickiego Street, Poznań 60-781, Poland E-mail: pjagodzi@am.poznan.pl

Key words: ten-eleven translocation 1-3, cervical cancer stratified by clinicopathological variables, as compared with non-cancerous cervical tissues.

\section{Introduction}

Cervical cancer (CC) is one of the most common solid tumors in females worldwide, and has a high mortality rate (1-3) due to asymptomatic development of the disease delaying diagnosis (4,5). CC is a gynecological malignancy associated with oncogenic human papillomavirus (HPV) infection $(6,7)$. In addition to HPV infection, other factors affect the development of $\mathrm{CC}$, including immunological disorders and genetic malfunctions such as point mutations, deletions, amplifications and rearrangements of DNA (6). Previous studies have suggested that epigenetic changes may significantly impact cervical carcinogenesis (6-9).

Epigenetic alterations are heritable traits that impact the regulation of gene expression without altering the DNA sequence (10). These traits control genetic and transcriptional activity during growth, differentiation or organism adaptation to environmental changes (6). One epigenetic mechanism of DNA methylation consists of cytosine methylation in cytosine-phosphate-guanine $(\mathrm{CpG})$ dinucleotide islands, located in the promoter region of numerous genes $(6,11,12)$. During malignant transformation, $\mathrm{CpG}$ islands become hypermethylated, silencing the expression of suppressor genes and leading to a loss in the control of cell proliferation $(13,14)$. By contrast, the hypomethylation of oncogenes increases cell division and enhances the metastasis of cancer cells (14). The process of methylation has been well characterized in recent years, but the underlying mechanism of demethylation, particularly during carcinogenesis, remains to be elucidated $(6,15,16)$. Ten-eleven translocation (TET) proteins have an important role in DNA demethylation, with reduced expression observed in various tumors $(6,13,17-22)$.

The TET protein family includes TET1, TET2 and TET3 (10,23). The TET1 and TET3 proteins use the CXXC zinc motif to bind to5-methylcytosine $(5-\mathrm{mC})$ in $\mathrm{CpG}$ islands $(16,17,24)$. The TET proteins have been revealed to catalyze the oxidation of 5-mC to 5-hydroxymethylcytosine 
(5-hmC) (25). Subsequently, 5-hmC is oxidized to 5-formylocytosine (5-fC) and 5-carboxycytosine (5-caC), eventually converting 5 - $\mathrm{mC}$ to cytosine $(13,17,26)$. This transformation may contribute to unlocking the promoter regions of suppressor genes and facilitating the development of cancer $(8,13,16)$. Low TET expression levels are correlated with decreased 5-hmC levels in malignant tissues and with clinicopathological features in various primary cancer tissues $(13,17,20,22,27)$. However, little is understood regarding the levels of TET expression in cervical cancerous and non-cancerous tissue. Therefore, the present study evaluated the expression levels of TET1, TET2 and TET3 transcripts in cervical cancerous $(n=80)$ and non-cancerous $(n=41)$ tissues. Furthermore, the TET1, TET2 and TET3transcript levels were compared in patient groups stratified by clinicopathological variables in primary CC and non-cancerous cervical tissues.

\section{Materials and methods}

Patients and tissue samples. Primary CC tissue samples were collected following surgical resection between June 2013 and August 2015 from 80 female Caucasian patients, which is representative of the female Polish population. Patients were treated at the Department of Radiotherapy and Gynecological Oncology Greater Cancer Center (Poznań, Poland). Non-cancerous cervical tissues were obtained from 41 women with uterine fibroids undergoing uterine surgical resection in the Division of Gynecological Surgery, Poznań University of Medical Sciences (Poznań, Poland).

At the time of surgery, the mean age of patients in the cancer and control groups was $58.6 \pm 11.4$ and $49.9 \pm 9.0$ years, respectively. Of the 80 females in the study group, 11 patients were classified as $<45$ years, 48 were aged $45-60$ and 21 were aged $>60$ years. Among the 41 women in the control group, 12 patients were classified as $<45$ years of age, 24 were aged 45-60 and 5 were $>60$ years. Among the 80 patients with CC, 4 patients were classified as stage I, 26 as stage II, 43 as stage III and 7 as stage IV, based on the International Federation of Gynecology and Obstetrics (FIGO) classification system and World Health Organization (28). Cancerous and non-cancerous cervical tissue samples were obtained following protocol approval by the Local Ethics Committee of Poznan University of Medical Sciences. Oral and written informed consent were obtained from all participants in the study. A portion of the tissue sample was immediately snap-frozen in liquid nitrogen and stored at $-80^{\circ} \mathrm{C}$ until RNA isolation. The remaining portion was used for histopathological assessment, which was performed by an experienced pathologist (Greater Poland Cancer Centre, Poznań, Poland).

Reverse transcription-quantitative polymerase chain reaction (RT-qPCR) analysis of TET transcript levels. Frozen tissue was homogenized and total RNA was isolated according to the protocol of Chomczyński and Sacchi (29). RNA quality was determined spectrophotometrically using a BioPhotometer ${ }^{\circledR}$ from Eppendorf AG (Hamburg, Germany) and 2\% agarose gel electrophoresis. RNA samples were reverse transcribed to cDNA using Moloney Murine Leukemia Virus (M-MLV) reverse transcriptase (Invitrogen; Thermo Fisher Scientific,
Inc., Waltham, MA, USA) according to the manufacturer's protocol. RT-qPCR was performed using a Light Cycler1480 real-time PCR detection system (Roche Diagnostics GmbH, Mannheim, Germany) using EvaGreen ${ }^{\circledR}$ (Solis BioDyne, Tartu, Estonia) as the detection dye. The thermal cycling conditions were as follows: 15 min activation, followed by 40 cycles consisting of $10 \mathrm{sec}$ denaturation at $95^{\circ} \mathrm{C}, 10 \mathrm{sec}$ annealing at $58^{\circ} \mathrm{C}, 10 \mathrm{sec}$ at $72^{\circ} \mathrm{C}$. The transcript levels for patients and controls were quantified by the relative quantification method using a calibrator, which is a standard curve described in the Relative Quantification Manual, Roche Diagnostics GmbH (Mannheim, Germany). The calibrator was prepared as a cDNA mix from all samples. For amplification, $1 \mu 1$ (total $20 \mu \mathrm{l}$ ) of cDNA using $9 \mu \mathrm{l}$ of $5 \mathrm{X}$ HOT FIREPol ${ }^{\circledR}$ EvaGreen $^{\circledR}$ qPCR Mix Plus (no ROX) (Solis BioDyne) was used. Primer sequences are presented in Table I. A total of $1 \mu \mathrm{l}$ of $10 \mu \mathrm{M}$ primer was used per reaction. All analyses included a negative control without cDNA, each experiment was repeated three times for all samples. The quantity of TET1, TET2 and TET3 transcripts in each sample was corrected by the measurement of porphobilinogen deaminase cDNA levels and expressed as a multiple of the copies in the calibrator.

Statistical analysis. Statistical analysis was performed with STATISTICA version 12 software (StatSoft, Inc., Tulsa, OK, USA) and Cytel Studio version 10.0 (Cytel Software Corporation, Cambridge, MA, USA). The data were presented as mean \pm standard deviation and median with range. For the comparison of variables with a normal distribution, the unpaired $t$-test was used; in other cases, the non-parametric Mann-Whitney U test or the Kruskal-Wallis test was used to calculate statistically significant differences between the compared mean values. $\mathrm{P}<0.05$ was considered to indicate a statistically significant difference.

\section{Results}

Significantly fewer TET1 transcripts $(\mathrm{P}=0.0000001)$ were present in primary $\mathrm{CC}$ tissue from all patients, compared with non-cancerous tissue from the control group (Table II; Fig. 1). However, there were no significant differences in TET2 $(\mathrm{P}=0.084040)$ and TET3 $(\mathrm{P}=0.068636)$ transcript levels between these groups (Tables III and IV; Fig. 1). Stratification of patients based on age, the FIGO classification system, grade of differentiation and histological features was performed to evaluate the differences in theTET1, TET2 and TET3 transcript levels between cancerous and non-cancerous tissues. Significantly fewer TET1 transcripts were observed in stage I $(\mathrm{P}=0.016)$, II $(\mathrm{P}<0.0001)$, III $(\mathrm{P}=0.00007)$, grade of differentiationG1 $(\mathrm{P}=0.026), \mathrm{G} 2(\mathrm{P}=0.00006), \mathrm{G} 3(\mathrm{P}=0.0007)$ and $\mathrm{Gx}(\mathrm{P}=0.0004)$ and squamous histological type $(\mathrm{P}<0.00001)$ cervical tissue samples, compared with non-cancerous tissue (Table II). TET1 transcript levels were significantly higher in CC tissue samples from patients aged 45-60 $(\mathrm{P}=0.0002)$ and patients aged $>60$ years $(\mathrm{P}=0.003)$, compared with controls (Table II). Furthermore, lower TET2 transcript levels were observed in CC tissue samples characterized as stage II $(\mathrm{P}=0.043)$, and lower TET3 transcript levels were detected in samples characterized as stage III $(\mathrm{P}=0.010)$, with a grade of differentiation of $\mathrm{G} 3(\mathrm{P}=0.025)$ and a squamous histological type $(\mathrm{P}=0.047)$, 
Table I. Primers used in reverse transcription-quantitative polymerase chain reaction analysis.

\begin{tabular}{lllll}
\hline Transcript & \multicolumn{1}{c}{ Forward (5'-3') } & Reverse (5'-3') & $\begin{array}{c}\text { Product } \\
\text { size, bp }\end{array}$ & $\begin{array}{c}\text { UCSC position } \\
\text { (GRCh37/hg 19) of genes }\end{array}$ \\
\hline TET1 & ATACAATGGGCACCCTACCG & GGGCTTGGGCTTCTACCAAA & 159 & chr10:70 320 117-70 454 239 \\
TET2 & GCTGACAAACTCTACTCGG & CTTCTGGCAAACTTACATCC & 188 & chr4:106 067 842-106 200 960 \\
TET3 & CCCAAAGAGGAAGAAGTG & GCAGTCAATCGCTATTTC & 129 & chr2:74 273 405-74 335 302 \\
PBGD & GCCAAGGACCAGGACATC & TCAGGTACAGTTGCCCATC & 160 & chr11:118 468 348-118468 864
\end{tabular}

UCSC, University of California Santa Cruz; TET, ten-eleven translocation; PBGD, porphobilinogen deaminase.

Table II. Statistical analysis of TET1 transcript levels in cervical cancer and non-cancerous tissues from patients stratified by age, FIGO stage, grade of differentiation and histological type of cancer.

\begin{tabular}{|c|c|c|c|c|c|c|}
\hline \multirow[b]{3}{*}{ Variables } & \multirow{2}{*}{\multicolumn{2}{|c|}{ No. of cases }} & \multicolumn{2}{|c|}{ Transcript } & \multirow{2}{*}{\multicolumn{2}{|c|}{ P-value }} \\
\hline & & & \multirow{2}{*}{$\begin{array}{l}\text { Cancerous tissue, } \\
\text { median (range) }\end{array}$} & \multirow{2}{*}{$\begin{array}{l}\text { Non-cancerous } \\
\text { tissue, median } \\
\text { (range) }\end{array}$} & & \\
\hline & Patients $(\%)$ & Controls (\%) & & & $\begin{array}{l}\text { Patients vs. } \\
\text { controls }^{\mathrm{e}}\end{array}$ & $\begin{array}{l}\text { Patients vs. } \\
\text { patients }^{\mathrm{f}}\end{array}$ \\
\hline Total no. of cases & 80 & 41 & $\begin{array}{c}2.563 \\
(1.740-4.273)\end{array}$ & $\begin{array}{c}3.262 \\
(2.212-3.957)\end{array}$ & $0.0000001^{\mathrm{c}}$ & - \\
\hline \multicolumn{7}{|l|}{$\operatorname{Age}^{\mathrm{a}}$} \\
\hline$>45$ & $11(13.75)$ & $13(31.70)$ & - & - & $0.157000^{\mathrm{b}}$ & - \\
\hline $45-60$ & $31(38.75)$ & $23(56.10)$ & $\begin{array}{c}2.522 \\
(1.740-4.274)\end{array}$ & $\begin{array}{c}3.378 \\
(2.441-3.957)\end{array}$ & $0.000200^{c}$ & - \\
\hline$>60$ & $38(47.50)$ & $5(12.20)$ & $\begin{array}{c}2.561 \\
(2.033-3.782)\end{array}$ & $\begin{array}{c}3.523 \\
(2.997-3.927)\end{array}$ & $0.003000^{\mathrm{c}}$ & - \\
\hline \multicolumn{7}{|l|}{ FIGO stage } \\
\hline I & $4(5.00)$ & - & $\begin{array}{c}2.385 \\
(2.272-3.122)\end{array}$ & & $0.016000^{\mathrm{c}}$ & $0.380176^{\mathrm{d}}$ \\
\hline II & $26(32.50)$ & - & $\begin{array}{c}2.507 \\
(1.999-3.311)\end{array}$ & & $<0.000100^{\mathrm{c}}$ & \\
\hline III & $43(53.75)$ & - & $\begin{array}{c}2.578 \\
(1.740-4.274)\end{array}$ & & $0.000070^{\mathrm{c}}$ & \\
\hline IV & $7(8.75)$ & - & $\begin{array}{c}2.827 \\
(2.096-3.667)\end{array}$ & & $0.075000^{\mathrm{c}}$ & \\
\hline \multicolumn{7}{|c|}{ Grade of differentiation } \\
\hline G1 & $5(6.25)$ & - & $\begin{array}{c}2.412 \\
(2.033-3.508)\end{array}$ & $\begin{array}{c}3.262 \\
(2.212-3.957)\end{array}$ & $0.026000^{c}$ & $0.464650^{\mathrm{d}}$ \\
\hline G2 & $36(45.00)$ & - & $\begin{array}{c}2.582 \\
(2.074-3.782)\end{array}$ & & $0.000060^{c}$ & \\
\hline G3 & $11(13.75)$ & - & $\begin{array}{c}2.418 \\
(1.999-3.812)\end{array}$ & & $0.000700^{c}$ & \\
\hline $\mathrm{G}_{\mathrm{x}}$ & $28(35.00)$ & - & $\begin{array}{c}2.577 \\
(1.740-4.274)\end{array}$ & & $0.000400^{\mathrm{c}}$ & \\
\hline \multicolumn{7}{|l|}{ Histological type } \\
\hline Squamous & $78(97.50)$ & - & $\begin{array}{c}2.564 \\
(1.740-4.274)\end{array}$ & & $<0.000010^{\mathrm{c}}$ & \\
\hline Adenocarcinoma & $2(2.50)$ & - & $\begin{array}{c}3.394 \\
(2.514-4.274)\end{array}$ & & $0.840000^{c}$ & $0.295441^{c}$ \\
\hline
\end{tabular}


Table III. Statistical analysis of TET2 transcript levels in cervical cancer and non-cancerous tissues from patients including age, FIGO stage, grade of differentiation and histological type of cancer.

\begin{tabular}{|c|c|c|c|c|c|c|}
\hline \multirow[b]{3}{*}{ Variables } & \multirow{2}{*}{\multicolumn{2}{|c|}{ No. of cases }} & \multicolumn{2}{|c|}{ Transcript } & \multicolumn{2}{|c|}{ P-value } \\
\hline & & & \multirow{2}{*}{$\begin{array}{l}\text { Cancerous tissue, } \\
\text { median (range) }\end{array}$} & \multirow{2}{*}{$\begin{array}{c}\text { Non-cancerous } \\
\text { tissue, median (range) }\end{array}$} & \multirow{2}{*}{$\begin{array}{l}\text { Patients vs. } \\
\text { controls }^{\mathrm{e}}\end{array}$} & \multirow{2}{*}{$\begin{array}{c}\text { Patients vs. } \\
\text { patients }^{\mathrm{f}}\end{array}$} \\
\hline & Patients $(\%)$ & Controls (\%) & & & & \\
\hline Total no. of cases & 80 & 41 & $\begin{array}{c}3.075 \\
(2.246-4.962)\end{array}$ & $\begin{array}{c}3.185 \\
(1.256-3.675)\end{array}$ & $0.084040^{c}$ & - \\
\hline \multicolumn{7}{|l|}{$\mathrm{Age}^{\mathrm{a}}$} \\
\hline$>45$ & $11(13.75)$ & $13(31.70)$ & - & - & $0.763000^{\mathrm{b}}$ & - \\
\hline $45-60$ & $\begin{array}{l}31 \\
\quad(38.75)\end{array}$ & $23(56.10)$ & $\begin{array}{c}3.075 \\
(2.246-4.781)\end{array}$ & $\begin{array}{c}3.185 \\
(1.256-3.625)\end{array}$ & $0.239000^{\mathrm{c}}$ & - \\
\hline$>60$ & $38(47.50)$ & $5(12.20)$ & $\begin{array}{c}3.099 \\
(2.362-4.962)\end{array}$ & $\begin{array}{c}3.243 \\
(3.122-3.675)\end{array}$ & $0.116000^{c}$ & - \\
\hline \multicolumn{7}{|l|}{ FIGO stage } \\
\hline I & $4(5.00)$ & - & $\begin{array}{c}3.077 \\
(2.887-3.675)\end{array}$ & & $0.735000^{\mathrm{c}}$ & $0.804017^{\mathrm{d}}$ \\
\hline II & $26(32.50)$ & - & $\begin{array}{c}3.015 \\
(2.489-4.183)\end{array}$ & & $0.043000^{\mathrm{c}}$ & \\
\hline III & $43(53.75)$ & - & $\begin{array}{c}3.100 \\
(2.246-4.962)\end{array}$ & & $0.256000^{c}$ & \\
\hline IV & $7(8.75)$ & - & $\begin{array}{c}3.086 \\
(2.625-3.905)\end{array}$ & & $0.539000^{c}$ & \\
\hline \multicolumn{7}{|c|}{ Grade of differentiation } \\
\hline G1 & $5(6.25)$ & - & $\begin{array}{c}2.899 \\
(2.647-4.781)\end{array}$ & $\begin{array}{c}3.185 \\
(1.256-3.675)\end{array}$ & $0.230040^{\mathrm{c}}$ & $0.809431^{\mathrm{d}}$ \\
\hline G2 & $36(45.00)$ & - & $\begin{array}{c}3.095 \\
(2.362-4.962)\end{array}$ & & $0.264000^{c}$ & \\
\hline G3 & $11(13.75)$ & - & $\begin{array}{c}3.029 \\
(2.489-3.394)\end{array}$ & & $0.093000^{c}$ & \\
\hline $\mathrm{G}_{\mathrm{x}}$ & $28(35.00)$ & - & $\begin{array}{c}3.099 \\
(2.246-3.694)\end{array}$ & & $0.243000^{\mathrm{c}}$ & \\
\hline \multicolumn{7}{|l|}{ Histological type } \\
\hline Squamous & $78(97.50)$ & - & $\begin{array}{c}3.075 \\
(2.246-4.962)\end{array}$ & & $0.085000^{\mathrm{c}}$ & \\
\hline Adenocarcinoma & $2(2.50)$ & - & $\begin{array}{c}3.089 \\
(2.833-3.345)\end{array}$ & & $0.708000^{c}$ & $0.902289^{c}$ \\
\hline
\end{tabular}

${ }^{\mathrm{a}} \mathrm{Age}$ at first diagnosis; ${ }^{\mathrm{b}}$ Student's $t$-test; 'Mann-Whitney U test; ${ }^{\mathrm{d}}$ Kruskal-Wallis test; ${ }^{\mathrm{e}}$ comparison of TET expression between patients and controls for all clinicopathological data; ${ }^{\mathrm{f} C o m p a r i s o n}$ of TET expression within selected groups of patients. FIGO, International Federation of Gynecology and Obstetrics; TET, ten-eleven translocation.

compared with samples from the non-cancerous control group (Tables III and IV). However, there were no significant differences between TET1, TET2 and TET3 transcript levels for I vs. II, III or IV, II vs. III or IV and III vs. IV FIGO stage (data not shown). Additionally, there were no significant differences between these transcript levels for G1 vs. G2, G3 or Gx, G2 vs. G3 or Gx and G3 vs. Gx for grade of differentiation, as well as for the histological type (data not shown).

\section{Discussion}

The involvement of TET1, TET2 and TET3 proteins in active demethylation at $\mathrm{CpG}$ islands in DNA has been previously documented $(14,16,30)$. A previous study reported that the three mouse Tet proteins (Tet1, Tet2 and Tet 3 ) may catalyze a similar reaction (12). TET1 is crucial for mouse embryonic stem (ES) cell maintenance via the regulation of methylation and the expression of the gene Nanog, which encodes a transcription factor essential for self-renewal of undifferentiated ES cells (12). A loss of TET proteins in ES cells has been demonstrated to be involved in the maintenance of DNA methylation patterns at several other DNA methylation regions (31).

The role of TET proteins in malignant transformation has been reported in animal models $(12,32)$. Removal of TET function induces the development of aggressive myeloid leukemia in a mouse model (32). TET1 expression is responsible for DNA 
Table IV. Statistical analysis of TET3 transcript levels in cervical cancer and non-cancerous tissues according to age, FIGO stage, grade of differentiation and histological type of cancer.

\begin{tabular}{|c|c|c|c|c|c|c|}
\hline \multirow[b]{2}{*}{ Variables } & \multicolumn{2}{|c|}{ No. of cases } & \multicolumn{2}{|c|}{ Transcript } & \multicolumn{2}{|c|}{ P-value } \\
\hline & Patients $(\%)$ & Controls $(\%)$ & $\begin{array}{l}\text { Cancerous tissue, } \\
\text { median (range) }\end{array}$ & $\begin{array}{c}\text { Non-cancerous } \\
\text { tissue, median (range) }\end{array}$ & $\begin{array}{c}\text { Patients } \\
\text { vs. controls }\end{array}$ & $\begin{array}{c}\text { Patients vs } \\
\text { patients }^{\mathrm{f}}\end{array}$ \\
\hline Total no. of cases & 80 & 41 & $\begin{array}{c}2.720 \\
(1.985-4.102)\end{array}$ & $\begin{array}{c}2.803 \\
(2.443-4.432)\end{array}$ & $0.068636^{\mathrm{b}}$ & - \\
\hline \multicolumn{7}{|l|}{$\operatorname{Age}^{\mathrm{a}}$} \\
\hline$>45$ & $11(13.75)$ & $13(31.70)$ & $\begin{array}{c}2.782 \\
(2.341-3.966)\end{array}$ & $\begin{array}{c}2.294 \\
(2.443-4.014)\end{array}$ & $0.242000^{\mathrm{b}}$ & - \\
\hline $45-60$ & $31(38.75)$ & $23(56.10)$ & $\begin{array}{c}2.675 \\
(2.055-3.742)\end{array}$ & $\begin{array}{c}2.761 \\
(2.446-4.432)\end{array}$ & $0.077000^{\mathrm{b}}$ & - \\
\hline$>60$ & $38(47.50)$ & $5(12.20)$ & $\begin{array}{c}2.742 \\
(1.986-4.102)\end{array}$ & $\begin{array}{c}2.725 \\
(2.616-3.022)\end{array}$ & $0.955000^{\mathrm{b}}$ & - \\
\hline \multicolumn{7}{|l|}{ FIGO stage } \\
\hline I & $4(5.00)$ & - & $\begin{array}{c}3.061 \\
(2.617-3.638)\end{array}$ & & $0.984000^{\mathrm{b}}$ & $0.222237^{c}$ \\
\hline II & $26(32.50)$ & - & $\begin{array}{c}2.912 \\
(2.268-4.102)\end{array}$ & & $0.676000^{\mathrm{b}}$ & \\
\hline III & $43(53.75)$ & - & $\begin{array}{c}2.621 \\
(1.986-4.048)\end{array}$ & & $0.010000^{\mathrm{b}}$ & \\
\hline IV & $7(8.75)$ & - & $\begin{array}{c}2.904 \\
(2.368-3.780)\end{array}$ & & $0.726000^{\mathrm{b}}$ & \\
\hline \multicolumn{7}{|c|}{ Grade of differentiation } \\
\hline G1 & $5(6.25)$ & - & $\begin{array}{c}2.396 \\
(2.331-3.742)\end{array}$ & $\begin{array}{c}2.803 \\
(2.443-4.432)\end{array}$ & $0.138000^{\mathrm{b}}$ & $0.498179^{c}$ \\
\hline G2 & $36(45.00)$ & - & $\begin{array}{c}2.846 \\
(1.994-4.102)\end{array}$ & & $0.453000^{\mathrm{b}}$ & \\
\hline G3 & $11(13.75)$ & - & $\begin{array}{c}2.680 \\
(2.341-3.404)\end{array}$ & & $0.025000^{\mathrm{b}}$ & \\
\hline $\mathrm{G}_{\mathrm{x}}$ & $28(35.00)$ & - & $\begin{array}{c}2.756 \\
(1.986-3.731)\end{array}$ & & $0.158000^{\mathrm{b}}$ & \\
\hline \multicolumn{7}{|l|}{ Histological type } \\
\hline Squamous & $78(97.50)$ & - & $\begin{array}{c}2.703 \\
(1.986-4.102)\end{array}$ & & $0.047000^{\mathrm{b}}$ & $0.109049^{b}$ \\
\hline Adenocarcinoma & $2(2.50)$ & - & $\begin{array}{c}3.542 \\
(3.466-3.618)\end{array}$ & & $0.215000^{\mathrm{b}}$ & \\
\hline
\end{tabular}

${ }^{\mathrm{a}} \mathrm{Age}$ at first diagnosis; ${ }^{\mathrm{b}} \mathrm{Student}$ 's $t$-test; ${ }^{\mathrm{c}}$ Mann-Whitney U test; ${ }^{\mathrm{d}}$ Kruskal-Wallis test; ${ }^{\mathrm{e}}$ comparison of TET expression between patients and controls for all clinicopathological data; ${ }^{\mathrm{f}}$ comparison of TET expression within selected groups of patients. FIGO, International Federation of Gynecology and Obstetrics; TET, ten-eleven translocation.

methylation of tissue inhibitors of metalloproteinase proteins 2 and 3 (TIMP2, TIMP3) in prostate and breast cancer (19). Reduced levels ofTET1, TET2 and TET3 have been associated with decreased 5-hmC levels in human breast, liver, lung, pancreatic and prostate cancer compared with the surrounding non-cancerous tissue (20). Decreased TET1 expression levels correspond to reduced 5-hmC levels in breast, prostate and hepatocellular cancer compared with normal tissue $(19,22)$. Du et al (27) demonstrated that the loss of 5-hmC in tumors is correlated with the downregulation of TET1 expression.

Rawłuszko-Wieczorek et al (13) observed reduced levels of TET1, TET2 and TET3 mRNA in in colorectal cancer tissue compared with non-cancerous tissue. The decreased TET1, TET 2 and TET3 mRNA levels were associated with various groups, including age, gender, cancer localization, histological grade, tumor node and metastasis classification. Furthermore, this study also demonstrated that patients with elevated TET2 transcript levels have more favorable overall survival (13). Another previous study demonstrated significantly lower levels of TET1 transcripts and protein in gastric cancer, which was correlated with gender, age and certain clinicopathological features including tumor localization, depth of invasion, lymph node metastasis, histological grade and histological type (17). Du et al (27) used liquid chromatography mass 


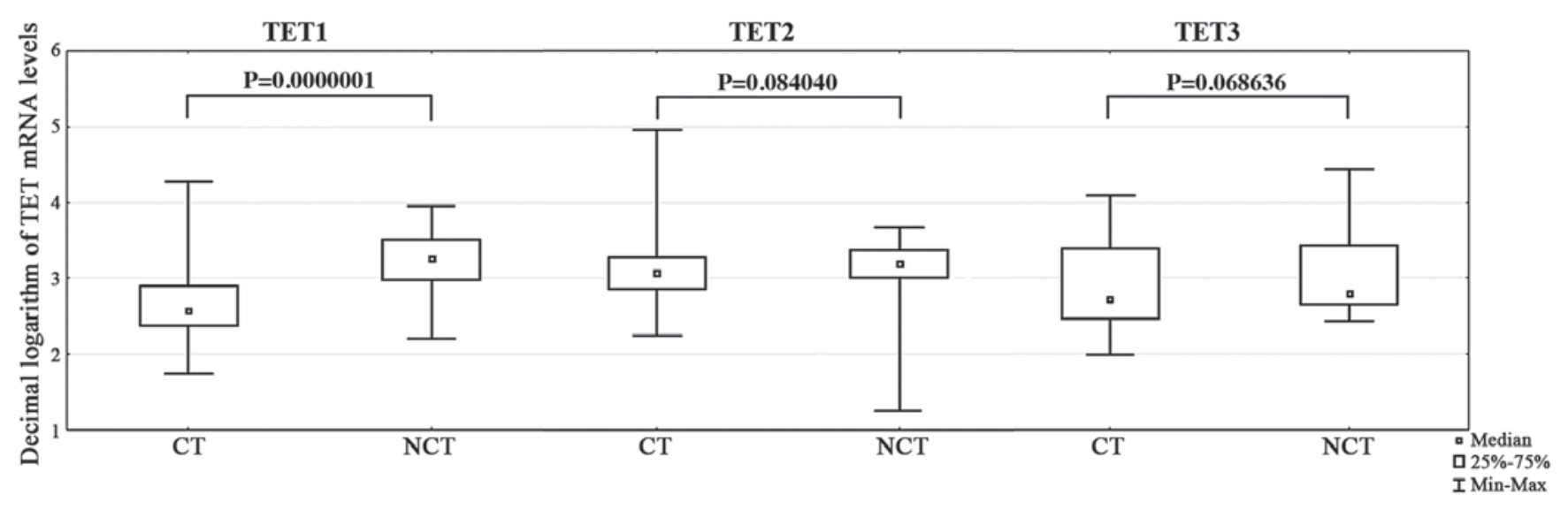

Figure 1. Comparison of TET1, TET2 and TET3 transcript levels in cervical cancer and non-cancerous tissue. CT was obtained from 80 patients with primary cervical cancer, and NCT were obtained from 41 women with uterine fibroids undergoing uterine surgical resection. Frozen tissue was homogenized and total RNA was isolated and reverse-transcribed to cDNA. The TET transcript levels for patients and controls were quantified by reverse transcription-quantitative polymerase chain reaction using the relative quantification method. The quantity of TET1, TET2 and TET3 transcripts in each sample was corrected to porphobilinogen deaminase cDNA levels and expressed as a multiplicity of these copies as a calibrator. The P-value was calculated using the Mann-Whitney test. P $<0.05$ was considered to be statistically significant. TET, ten-eleven translocation; CT, cancerous tissue; NCT, non-cancerous tissue.

spectrometry/mass spectrometry to demonstrate very low levels of 5-fC and 5-caC and decreased levels of 5-hmC in gastric cancer tissue compared with adjacent non-cancerous tissue. In addition, the authors revealed that the reduction of 5-hmC in gastric cancer was primarily associated with decreased TET1 expression (27). Using immunochemistry analysis, Müller et al (21) demonstrated that the exclusion ofTET1 from nuclei was associated with a loss of 5-hmC in the genomic DNA of gliomas. The depletion ofTET1 in prostate and breast cancer tissues has also been observed. TET1 deficiency promotes tumor growth, cell invasion and cancer metastasis in prostate xenograft mouse models (19). Furthermore, TET1 reduction corresponds to a poor survival outcome in patients with breast cancer (19). Decreased TET1 levels are responsible for maintaining the methylation of TIMP2 or TIMP3, which correlates with advanced node status in clinical samples (19).

In conclusion, to the best of our knowledge the current study is the first to demonstrate a significant reduction in the levels of TET1 transcripts in cancerous tissues compared with non-cancerous samples. In addition, TET1, TET2 and TET3 transcript levels were revealed to be reduced in patients with primary CC stratified according to their clinicopathological data, in comparison with non-cancerous tissues. The present study did not evaluate TET protein in conjunction with 5-hmC levels. Therefore, further studies are required to evaluate the potential correlation between 5 -hmC levels and TET expression in $\mathrm{CC}$ tissues, and their associations with clinical characteristics.

\section{Acknowledgements}

The authors would like to thank the patients enrolled in the study for their participation. In addition, the authors would like to acknowledge Hanna Drzewiecka and BartoszSłowikowski (both Poznań University of Medical Sciences, Poznań, Poland) or their invaluable assistance. This study was supported by Poznań University of Medical Sciences, Poland (grant no. 502-01-01124182-07474).

\section{References}

1. Deręgowska J: Women with breast cancer in the network of social support-a quantitative context. Nowiny Lekarskie 81: 203-213, 2012.

2. Wang X, Tang S, Le SY, Lu R, Rader JS, Meyers C and Zheng ZM: Aberrant expression of oncogenic and tumor-suppressive MicroRNAs in cervical cancer is required for cancer cell growth. PLoS One 3: e2557, 2008.

3. Parkin DM, Bray F, Ferlay J and Pisani P: Estimating the world cancer burden: Globocan 2000. Int J Cancer 94: 153-156, 2001.

4. Ibeanu OA: Molecular pathogenesis of cervical cancer. Cancer Biol Ther 11: 295-306, 2011.

5. Asih TS, Lenhart S, Wise S, Aryati L, Adi-Kusumo F, Hardianti Ms and Forde J: The dynamics of Hpv infection and cervical cancer cells. Bull Math Biol 78: 4-20, 2016.

6. Jiménez-Wences H, Peralta-Zaragoza $\mathrm{O}$ and Fernández-Tilapa G: Human papilloma virus, DNA methylation and microRNA expression in cervical cancer (Review). Oncol Rep 31: 2467-2476, 2014.

7. Faridi R, Zahra A, Khan K and Idrees M: Oncogenic potential of Human Papillomavirus (HPV) and its relation with cervical cancer. Virol J 8: 269, 2011.

8. Fang J, Zhang H and Jin S: Epigenetics and cervical cancer: From pathogenesis to therapy. Tumour Biol 35: 5083-5093, 2014.

9. Zhang X, Zhang L, Tian C, Yang L and Wang Z: Genetic variants and risk of cervical cancer: Epidemiological evidence, meta-analysis and research review. BJOG 121: 664-674, 2014.

10. Li D, Guo B, Wu H, Tan L and Lu Q: TET family of dioxygenases: crucial roles and underlying mechanisms. Cytogenet Genome Res 146: 171-180, 2015.

11. Abdel-Wahab O, Mullally A, Hedvat C, Garcia-Manero G, Patel J, Wadleigh M, Malinge S, Yao J, Kilpivaara O, Bhat R, et al: Genetic characterization of TET1, TET2 and TET3 alterations in myeloid malignancies. Blood 114: 144-147, 2009.

12. Ito S, D'Alessio AC, Taranova OV, Hong K, Sowers LC and Zhang Y: Role of tet proteins in $5 \mathrm{mC}$ to $5 \mathrm{hmC}$ conversion, ES-cell self-renewal and inner cell mass specification. Nature 466: 1129-1133, 2010.

13. Rawłuszko-Wieczorek AA, Siera A, Horbacka K, Horst N, Krokowicz P and Jagodziński PP: Clinical significance of DNA methylation mRNA levels of TET family members in colorectal cancer. J Cancer Res Clin Oncol 141: 1379-1392, 2015.

14. Rawłuszko-Wieczorek AA, Siera A and Jagodziński PP: TET proteins in cancer: Current 'state of the art'. Crit Rev Oncol Hematol 96: 425-436, 2015.

15. Saavedra KP, Brebi PM and Roa JC: Epigenetic alterations in preneoplastic and neoplastic lesions of the cervix. Clin Epigenetics 4: 13, 2012.

16. Głowacki S and Błasiak J: Role of 5-hydroxymethylcytosine and TET proteins in epigenetic regulation of gene expression. Postepy Biochem 59: 64-69, 2013 (In Polish). 
17. Frycz BA, Murawa D, Borejsza-Wysocki M, Marciniak R Murawa P, Drews M, Kołodziejczak A, Tomela K and Jagodziński PP: Decreased expression of ten-eleven translocation 1 protein is associated with some clinicopathological features in gastric cancer. Biomed Pharmacother 68: 209-212, 2014.

18. Kudo Y, Tateishi K, Yamamoto K, Yamamoto S, Asaoka Y, Ijichi H, Nagae G, Yoshida H, Aburatani H and Koike K: Loss of 5-hydroxymethylcytosine is accompanied with malignant cellular transformation. Cancer Sci 103: 670-676, 2012.

19. Hsu CH, Peng KL, Kang ML, Chen YR, Yang YC, Tsai CH, Chu CS, Jeng YM, Chen YT, Lin FM, et al: TET1 suppresses cancer invasion by activating the tissue inhibitors of metalloproteinases. Cell Rep 2: 568-579, 2012.

20. Yang H, Liu Y, Bai F, Zhang JY, Ma SH, Liu J, Xu ZD, Zhu HG, Ling ZQ, Ye D, et al: Tumor development is associated with decrease of TET gene expression and 5-methylcytosine hydroxylation. Oncogene 32: 663-669, 2013.

21. Müller T, Gessi M, Waha A, Isselstein LJ, Luxen D, Freihoff D, Freihoff J, Becker A, Simon M, Hammes J, et al: Nuclear exclusion of TET1 is associated with loss of 5-hydroxymethylcytosine in IDH1 wild-type gliomas. Am J Pathol 181: 675-683, 2012.

22. Liu C, Liu L, Chen X, Shen J, Shan J, Xu Y, Yang Z, Wu L, Xia F, Bie P, et al: Decrease of 5-hydroxymethylcytosine is associated with progression of hepatocellular carcinoma through downregulation of TET1. PLOS One 8: e62828, 2013.

23. Afanas'ev I: Mechanisms of superoxide signaling in epigenetic processes: Relation to aging and cancer. Aging Dis 6: 216-227, 2015.

24. Fan M, He X and Xu X: Restored expression levels of TET1 decrease the proliferation and migration of renal carcinoma cells. Mol Med Rep 12: 4837-4842, 2015.
25. Tahiliani M, Koh KP, Shen Y, Pastor WA, Bandukwala H, Brudno Y, Agarwal S, Iyer LM, Liu DR, Aravind L and Rao A: Conversion of 5-methylcytosine to 5-hydroxymethylcytosine in mammalian DNA by MLL partner TET1. Science 324: 930-935, 2009.

26. Guz J, Jurgowiak M and Oliński R: Oxidation and deamination of nucleobases as an epigenetic tool. Postepy Hig Med Dosw (Online) 66: 275-286, 2012 (In Polish).

27. Du C, Kurabe N, Matsushima Y, Suzuki M, Kahyo T, Ohnishi I, Tanioka F, Tajima S, Goto M, Yamada $\mathrm{H}$, et al: Robust quantitative assessments of cytosine modifications and changes in the expressions of related enzymes in gastric cancer. Gastric Cancer 18: 516-525, 2015.

28. Böcker W: WHO classification of breast tumors and tumors of the female genital organs: Pathology and genetics. Verh Dtsch Ges Pathol 86: 116-119, 2002 (In German).

29. Chomczynski P and Sacchi N: Single-step method of RNA isolation by acid guanidinium thiocyanate-phenol-chloroform extraction. Anal Biochem 162: 156-159, 1987

30. He YF, Li BZ, Li Z, Liu P, Wang Y, Tang Q, Ding J, Jia Y, Chen Z, $\mathrm{Li}$ L, et al: Tet-mediated formation of 5-carboxylcytosine and its excision by TDG in mammalian DNA. Science 333: 1303-1307, 2011.

31. Liu L, Mao SQ, Ray C, Zhang Y, Bell FT, Ng SF, Xu GL and Li X: Differential regulation of genomic imprinting by TET proteins in embryonic stem cells. Stem Cell Res 15: 435-443, 2015.

32. An J, González-Avalos E, Chawla A, Jeong M, López-Moyado IF, Li W, Goodell MA, Chavez L, Ko M and Rao A: Acute loss of TET function results in aggressive myeloid cancer in mice. Nat Commun 6: 10071, 2015. 